Copyright (C) 2015 by Academic Publishing House Researcher

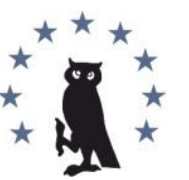

Published in the Russian Federation

European Researcher

Has been issued since 2010.

ISSN 2219-8229

E-ISSN 2224-0136

Vol. 95, Is. 6, pp. 416-420, 2015

DOI: 10.13187/er.2015.95.416

www.erjournal.ru

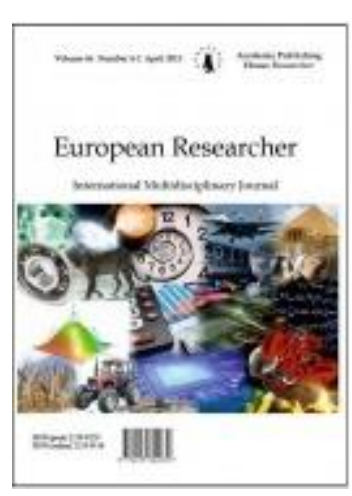

Historical Sciences and archaeology

Исторические науки и археология

UDC 930

\title{
Creative Heritage of S. N. Semanov as a Historical Source on the Political History USSR of the 1970th - the 1980th
}

\author{
${ }^{1}$ Anna A. Kudrina \\ ${ }^{2}$ Artjom A. Fomenkov \\ 3 Olga S. Rybkina
}

\begin{abstract}
${ }^{1}$ Nizhny Novgorod state university N.I. Lobachevsky, Russian Federation
${ }^{2}$ Nizhny Novgorod state university N.I. Lobachevsky, Russian Federation

Associate Professor

E-mail: artjom2310@inbox.ru

3 Nizhny Novgorod institute of management of the Russian academy

national economy and public service, Russian Federation

Associate Professor
\end{abstract}

\begin{abstract}
In work is considered various works of the prominent Soviet writer and journalist, the convinced Russian national patriot as a historical source. There are revealed the reason of the importance of memoirs and reflections of public figures of the late Soviet era as historical sources. The most significant aspects of a creative heritage of S.N. Semanov for modern historians are defined. The important historical events which found reflections in S. N. Semanov's works are specified. patriot.

Keywords: S. N. Semanov, historical source, "stagnation", reorganization, Russian national

\section{Введение}

Последние 10 лет стали своего рода водоразделом. События ещё советского периода, включая не только эпоху «застоя», но даже и годы перестройки. Отчасти не выглядит даже удивительным, что современные студенты плохо ориентируются в реалиях тех лет, зачастую даже неверно упоминая фамилии глава советского государства в хронологической последовательности (во всяком случае, «списать» этот факт только на низкий уровень преподавания Отечественной истории вряд ли возможно). Иначе говоря, советский период уже окончательно стал историей. Важно также отметить, что уходят из жизни не только политические деятели тех лет (последний яркий пример тому - кончина Е.М. Примакова),
\end{abstract}


но также и представители интеллектуального сообщества, оказывавшие влияние не только на умонастроения населения, но также и на процесс принятия политических решений.

\section{Методы и материалы}

Одним из таких людей, вне всяких сомнений, являлся Сергей Николаевич Семанов (1934-2011). Из его наиболее значимых постов уместно указать должность главного редактора в весьма популярном в 1970-1980-е годы журнале «Человек и закон». По мнению видного современного исследователя русского национализма Н. Митрохина, С.Н. Семанов являлся одним из наиболее значимых коммуникаторов, связывающих между собой последователей русского национал-патриотизма из разных социальных групп [1]. Кроме того, как отмечал сам С.Н. Семанов, «мы сознательно ставили цель добраться до души среднего партработника, служащего, чиновника правоохранительных органов, офицеров и генералов армии. Когда добирались до них, имели ощутимый гражданский успех» [2]. Иначе говоря, основной задачей С.Н. Семанов и его единомышленники из числа части столичных русских национал-патриотов считали просвещение советской партийнохозяйственной элиты «второго» эшелона.

Нельзя не отметить одного весьма значимого обстоятельства. Связано оно с тем, что многие документы, проливающих свет на политическую историю нашей страны 1970-х 1980-х годов, утрачены. Архивы пока не могут «похвастаться» большим пластом материалов по означенному периоду (официальные документы в данном случае не в счёт). Во-первых, у российских архивов не всегда имеются возможности для систематизации поступивших материалов. Как следствие, ряд документов, находящихся на хранении в архивах, исследователям по-прежнему недоступен. Во-вторых, в результате перевода ряда архивных документов в другие хранилища часть материалов в настоящее время также закрыта для исследователей. Наиболее яркий пример, подтверждающий данное положение, - ситуация с так называемым Центром документации «Народный архив», созданным в 1988 году по инициативе группы преподавателей (прежде всего речь идёт о Б.С. Илизарове) и студентов Московского Государственного Историко-Архивного института для принятия на хранение материалов о жизни рядовых граждан СССР и содержавший среди прочих материалов и документы по истории общественных организаций. Этот архив по своей сути не имел аналогов во всём мире [3]. Определённый период времени этими материалами исследователи могли достаточно свободно пользоваться, однако в 2006 году фонды были перевезены в Российский государственный архив новейшей истории (РГАНИ) и вплоть до настоящего времени они недоступны. То есть, источниковая база по истории СССР 1970-х 1980-х годов вряд ли может быть признана оптимальной для комплексного изучения данного периода.

К чести С.Н. Семанова в этой связи необходимо отметить, что при жизни он успел оставить для всех интересующихся политической историей СССР последних десятилетий обширное наследие. В первую очередь это, разумеется, касается его дневниковых записей, причём исследователям доступны как сокращённая [4], так и полная версия таковых [5].Относительно дневниковых записей С.Н. Семанова укажем, что именно этот источник даёт наиболее чёткие представления о политических взглядах автора, так как написан он по горячим следам событий, а не в результате осмысления (и, что вполне возможно, переосмысления) таковых через энное количество лет. С нашей точки зрения, особенно важными являются фрагменты дневника, посвящённые выборам народных депутатов РСФСР [6], а также идеи относительно внутренней политики в Закавказье [7].

Ряд выпущенных С.Н. Семановым монографий в трудно определяемом на первый взгляд жанре [8] - «Андропов: семь тайн генсека с Лубянки» [9], «Брежнев: Правитель золотого века» [10], «Русско-еврейские разборки» [11], «Русские для России» [12] и «Юрий Андропов. Генсек из КГБ» [13] - также следует причислить к важным историческим источникам по истории СССР 1970-х - 1980-х годов. В какой-то степени правомерным является утверждение, что упомянутые выше работы С.Н. Семанова посвящены прежде всего вопросам борьбы Ю.В. Андропова с его противниками - прорусски мыслящими представителями партийного, советского и хозяйственного аппарата, а также деятелями культуры. Учитывая то обстоятельство, что С.Н. Семанов сам является видным русским 
патриотом (и даже одним из идеологов данного направления - ведь именно его перу принадлежит нашумевшая статья «О ценностях относительных и вечных» [14], сыгравшая большую роль в становлении русистского движения в СССР), можно сделать вывод, что отмеченные нами работы содержат среди прочего авторские воспоминания о внутриполитических процессах в стране в 1960-е - 1980-е годы, в том числе и о периоде, породившем различные новые образования политического характера [15].

В целом же упомянуты работы представляют собой ценный источник по истории политической мысли СССР второй половины XX века. При этом не обойдём также внимание и то обстоятельство, что С.Н. Семанов привёл на страницах данных книг тексты ряда документов той эпохи, в частности, секретной записки Ю.В. Андропова в ЦК КПСС, датированной 28 марта 1981 года (кроме книги С.Н. Семанова она опубликована также в упоминавшемся выше сборнике «К не нашим», а также в журнале «Источник» [16]). Как известно, в данном документе речь шла об опасности, связанной с усилением русофильских тенденций в СССР. Нельзя игнорировать и то обстоятельство, что написан был текст «Об антисоветской деятельности Иванова А.М. и Семанова С.Н.» главой КГБ, то есть едва ли не самым информированным человеком в СССР. Впрочем, укажем, что этот текст, хотя и был создан на основе оперативной информации, содержал в себе и ложные утверждения, которые, судя по всему, объяснялись не недостаточным знанием Ю.В. Андропова ситуации в диссидентском движении, а особенностями его видения внутренней политики СССР.

Кроме того, С.Н. Семанов, будучи профессиональным историком (в своё время ему была присвоена учёная степень кандидата исторических наук, а докторская степень ему так и не была присуждена после защиты в 1974 году [17]), оказывал содействие молодым историкам, занимающимся изучением политической историей позднего СССР. Это касается не только упомянутого уже нами выше Н.А. Митрохина, который без помощи С.Н. Семанова вряд ли смог бы написать столь фундаментальный труд о русских национал-патриотах, который у него в итоге получился. С.Н. Семанов совместно с молодой московской исследовательницей А.А. Лотаревой составил сборник документов под названием «К не нашим. Из истории русского патриотического движения» [18]. В нём опубликованы прежде всего программные статьи 1960-1970-х годов, оказавшие влияние на становление и развитие русского национал-патриотического движения. Кроме того, на страницах данной работы присутствуют наиболее значимые материалы, написанные оппонентами русского патриотического лагеря - имеются в виду статья «Против антиисторизма» А.Н. Яковлева и «Записка об антисоветской деятельности Иванова А.М. и Семанова С.Н.» Ю.В. Андропова. Нашлось здесь также место для письма под названием «Без надлежащей взыскательности», написанного в 1972 году Д. Лихачёвым, Д. Благим, С. Мишинским и С. Поспеловым и направленным против нарождавшегося русского патриотического движения.

\section{Заключение}

Таким образом, следует признать, что С.Н. Семанов в отличие от ряда своих современников и единомышленников оставил обширное творческое наследие, являющееся ценным источником по политической истории СССР 1970-х - 1980-х годов. В его работах гармонично переплетаются описание политических событий с точки зрения человека, имеющего обширный связи в том числе и в «верхах» (впрочем, «жареных» фактов о деятельности членов Политбюро ЦК КПСС в его трудах по большому счёту нет), с собственными размышлениями о желательном русском национально ориентированном государственном строе и планами единомышленников по установлению такового. Разумеется, работы С.Н. Семанова страдают субъективизмом, однако, во-первых, этим отличаются практически все источники мемуарного характера, а, во-вторых, ценность представленных им сведений перекрывает негативные стороны его наследия.

\section{Примечания:}

1. Митрохин Н. Русская партия: движение русских националистов в СССР. 1953-1985 годы.М.: Новое литературное обозрение, 2003. С. 380.

2. Семанов С.Н. Юрий Андропов. Генсек из КГБ. М.: Алгоритм, 2011. С. 195-196. 
3. Илизаров Б. И Слово воскрешает... или «Прецедент Лазаря»: 25 тезисов и развернутое дополнение к светской теории воскрешения: по материалам Народного архива. М. - СПб.: Летний сад, 2007. С. 8.

4. Семанов С.Н. Дневник 1990 года // Новое литературное обозрение. 2007. № 84. C. 691-714.

5. Семанов С. Дневник 1990 года. URL: http://www.nlobooks.ru/rus/ magazines /nlo/196/328/401 C. 691.

6. Семанов С.Н. Дневник 1990 года // Новое литературное обозрение. 2007. № 84.

7. Там же. С. 691-692.

8. Зубков С.А. Рецензия на книгу: Семанов С. Брежнев: правитель «золотого века» // Новый исторический вестник. 2006. № 15. С. 297-299.

9. Семанов С. Андропов: 7 тайн генсека с Лубянки. М.: Вече, 2001. 415 с.

10. Семанов С. Брежнев: Правитель «золотого века». М.: Вече, 2002. 397 с. $389 \mathrm{c}$.

11. Семанов, С. Русско-еврейские разборки вчера и сегодня. М.: Альтернатива, 2004.

12. Семанов С. Русские для России. М.: Алгоритм, 2010. 462 с.

13. Семанов, С. Юрий Андропов. Генсек из КГБ. М.: Алгоритм, 2011. 347 с.

14. Семанов С. О ценностях относительных и вечных // Молодая гвардия. 1970. № 8. C. 308-320.

15. Skobelina N.A. Development of Social Movements in Russia in XVII-XXI Centuries // European researcher. 2013. № 11-1 (62). p. 2578-2586.

16. «Пресечь враждебные проявления «русизма»» // Источник. 1994. № 6. С. 108-110.

17.Новиков М.С., Новиков С.В. К вопросу о классификации националистических идей и организаций России. 1960 - 2000 гг. // Омский научный вестник. 2013. № 4 (121). С. 34-37.

18. К не нашим. Из истории русского патриотического движения / Сост. С. Семанов, А. Лотарева. Коммент. С. Семанов, А. Лотарева и К. Титов. М.: «ИХТИОС», 2006. 408 с.

\section{References:}

1. Mitrokhin N. Russkaya partiya: dwigenie russkikh nationalistov v SSSR. 1953-1985 gody. M.: Novoe literaturnoe obozrenie, 2003. S. 380.

2. Semanov S.N. Yuri Andropov. Gensek iz KGB. M.: Algoritm, 2011. S. 195-196.

3. Ilizarov B. I Slovo voskreshaet... ili «Prezedent Lazarya»: 25 tezisov I razvernutoe dopolnenie k swetskoy teorii woskresheniya: po materialam Narodnogo arkhiva. M. - SPb.: Letny sad, 2007. S. 8.

4. Semanov S.N. Dnevnik 1990 goda // Novoe literaturnoe obozrenie. 2007. № 84. S. 691-714.

5. Semanov S. Dnevnik 1990 goda. URL: http://www.nlobooks.ru/rus/magazines /nlo/196/328/401

6. Semanov S.N. Dnevnik 1990 goda // Novoe literaturnoe obozrenie. 2007. № 84. S. 691.

7. Ibid. S. 691-692.

8. Zubkov S.A. Rezenziya na knigu: Semanov S. Bregnev: pravitel «zolotogo veka» // Novy istorichesky vestnik. 2006. № 15. S. 298.

9. Semanov S. Andropov: 7 tain genseka s Lubyanki. M.: Veche, 2001. $415 \mathrm{~s}$.

10. Semanov S. Bregnev: pravitel «zolotogo veka». M.: Veche, 2002. 397 s.

11. Semanov S. Russko-evreyskiye razborki vchera I segodnya. M.: Alternativa, 2004. $389 \mathrm{~s}$.

12. Semanov S. Russkie dlya Rossii. M.: Algoritm, 2010. $462 \mathrm{~s}$.

13. Semanov S.N. Yuri Andropov. Gensek iz KGB. M.: Algoritm, 2011. 347 s.

14. Semanov S. O zennostyakh otnositelnykh I vechnykh // Molodaya gwardiya 1970. № 8. S. $308-320$.

15. Skobelina N.A. Development of Social Movements in Russia in XVII-XXI Centuries // European researcher. 2013. № 11-1 (62). p. 2578-2586.

16. «Presech vragdebnye proyavleniya «ruzizma»»// Istochnik. 1994. № 6. S. 108-110.

17.Novikov M.S., Novikov S.V. K voprosu o klassifikatii nationalisticheskikh idey I organizazij Rossii. 1960-2000 gg. // Omsky nauchny vestnik. 2013. № 4 (121). S. 34-37. 
18. K ne nashim. Iz istorii russkogo patrioticheskogo dwigeniya / Sost. S. Semanov, A. Lotareva. Komment. S. Semanov, A. Lotareva i K. Titov. M.: «IHTIOS», 2006. 408 s.

УДК 930 Творческое наследие С.Н. Семанова как исторический источник
по истории СССР 1970-1980-х годов

${ }^{1}$ Анна Андреевна Кудрина

2 Артём Александрович Фоменков

з Ольга Сергеевна Рыбкина

1 Нижегородский государственный университет им. Н.И. Лобачевского, Российская Федерация

2 Нижегородский государственный университет им. Н.И. Лобачевского, Российская Федерация

Кандидат исторических наук, доцент

E-mail: artjom2310@inbox.ru

3 Нижегородский институт управления Российской академии народного хозяйства и государственной службы, Российская Федерация

доцент

Аннотация. В работе рассматривается различные работы видного советского литератора и журналиста, убеждённого русского национал-патриота как исторический источник. Выявлены причина значимости воспоминаний и размышлений общественных деятелей позднесоветской эпохи как исторических источников. Определены наиболее значимые аспекты творческого наследия С.Н. Семанова для современных историков. Указаны важные исторические события, нашедшие отражения в работах С.Н. Семанова.

Ключевые слова: С.Н. Семанов, исторический источник, «застой», перестройка, русский национал-патриот. 